\title{
RECONFIGURING THE HEALTH SYSTEM FINANCING MECHANISM UNDER PANDEMIC SHOCK CONDITIONS
}

https://doi.org/10.47743/jopafl-2021-21-02

\author{
Cristina COPĂCEANU \\ University of European Political and Economic Studies "Constantin Stere", \\ Faculty of Economics and Ecology, \\ Chisinau, Republic of Moldova \\ https://orcid.org/0000-0003-3944-5982 \\ copaceanu_c@yahoo.com \\ Nadejda BOTNARI \\ Academy of Economic Studies, Faculty of Finance, \\ Chisinau, Republic of Moldova \\ nibotnari@mail.ru
}

\begin{abstract}
Today, the whole world is facing an extremely aggressive pandemic that affects all government systems and processes, including the health care system. Therefore, this article substantiates the need to reconfigure the financing mechanisms of the health system and to take measures to overcome pandemic shocks. The aim of this research is to highlight the existing problems in the efficient functioning of the financing mechanisms, but also to reconfigure them in the context of the pandemic crisis. The main results obtained from the investigations consist in carrying out a comprehensive diagnosis of the existing financing mechanisms, defining the financial shock of the health care system, as well as offering practical recommendations for the institutions empowered with the management of the health system. The uncertainty we are in requires us to find new opportunities to develop and maintain the mechanisms for the health system financing.
\end{abstract}

Keywords: financing mechanism, health system, shock, pandemic, crisis.

JEL Classification: H51; H12; G01.

This Article was presented as a paper at the $13^{\text {th }}$ edition of the Annual International Conference Globalization and Higher Education in Economics and Business Administration (GEBA 2021), which was held at the Alexandru Ioan Cuza University, Faculty of Economics and Business Administration in Iasi, Romania from the $21^{\text {st }}$ to $23^{\text {rd }}$ of October 2021.

\section{Introduction}

The topicality of the study derives from the fact that the health systems around the world are constantly changing, being affected by the emergence of new diseases, pandemics (COVID-19) but also by the need for resources (financial, human, technical, etc.) necessary for their treatment/prophylaxis. One of the most important problems, at national level, is the efficient management of financial resources funds. The main actor in the system of compulsory health insurance in the Republic of Moldova belongs to the 
National Health Insurance Company, which plays an important role in the process of allocating state budget funds and, in fact, representing a macroeconomic organization. Medical institutions are the main providers of medical services in the country, having the role of managing the budgetary funds. In the scientific attempt to reconfigure the financing mechanisms of the health care system in the Republic of Moldova, in conditions of pandemic shocks, we mention that the financing process in this field continues to be a current problem, because the mechanisms used are inefficient, which generates public money waste. It should be noted that the funds of medical services come largely from the population, while the collection mechanisms include: taxes, health insurance contributions, private insurance premiums, savings of the population, payments made directly by patients, donations, loans, grants, etc. [9, p.27].

At present, the compulsory health insurance in the Republic of Moldova is at a modest level due to the lack of financial and medical education, miserable salaries, the absence of fiscal incentives and, last but not least, the pandemic shocks that caused the medical, economic, financial psychological, but also social crisis. The recession of 2020 has exacerbated and further affected health systems, and the actors involved in managing the systems will have to cut back on planned spending, even staffing.

In some authors' opinion, the reconfiguration of the financing mechanisms of the health system derives, first of all, from the pandemic shock generated by COVID-19, which extended to the entire national health system and beyond. Thus, the pandemic shock caused by COVID-19, requires us to strengthen the capabilities of the national health system through all the available mechanisms and tools.

\section{Data sources and methods used}

As sources of information, the author used the statistical data of the World Health Organization, the Ministry of Health, Labour and Social Protection, the National Agency for Public Health, etc. In the paper, the authors used classical methods of analysis and synthesis, induction and deduction, history and logic, comparative and systemic analysis, as well as a contemporary approach to the trends of the COVID-19 pandemic.

\section{Analysis and interpretation of results}

Currently, the world economy is in a critical financial situation, that is why many countries have started to save on healthcare. Countries with a low level of socio-economic development, also refers to the Republic of Moldova, hardly cope with the economic and financial crisis, which causes an increase in poverty, which in turn directly affects the health of society. It should be mentioned that the COVID-19 pandemic highlighted the inefficiency, vulnerability and shortcomings of the national health system.

Pandemic shocks require us to investigate more detailly the problematic aspects of the financing mechanism of the health system. Therefore, for the beginning we will define the concept of mechanism by which we understand, first of all, a correlated set of financial relations, thus giving it the system significance. The system is a set of institutions, processes and behaviours that have established certain relationships between them. Secondly, we understand the notion of mechanism as a set of rules for transforming the effect of using advanced funds, especially consumed, in financial results [7, p.8]. 
The important thing is that the financing mechanism is integrated in two ways:

- as a subsystem - component part of the financial mechanism of the entity;

- as a system, which includes several components. Each form of financing has its own mechanism of realization, its elements and instruments.

The financing mechanism also differs within different entities, being determined by the organizational-legal form of the economic agent, the degree of association with other enterprises, the level of centralization of the financial resources' management, etc. The functioning of an entity financing mechanism involves the study of three basic elements [7, p.17]:

1) determination of the financing need - it is performed depending on the financing need of the investments and the current needs of the entity;

2) determining the sources of financing - is done taking into account the possibilities of access of the entity to different sources of financing;

3) determining the financing structure - is done so that the combination of different sources of financing to ensure minimum costs of financial resources and maximum effects.

Therefore, the financing mechanism of the health system is a combination of public and private resources. As public spending may not increase significantly in the future due to high public deficits, the main challenge for the decision makers is to bring more money into the system from private sources. In the case of the Republic of Moldova, the main private resources must be private health insurance and co-payments.

The researcher Copăceanu Cr. considers that the financing mechanism of the health care system is a whole set of actions of insurance, distribution and control of financial resources for a long-term perspective, based on contributions, taxes and co-payments, which will contribute to the achievement of strategic objectives of medical service providers [3]. With regard to the mechanisms for financing the European health systems through which funds are collected and allocated, we note that they are particularly complex and differ from one country to another. With the emergence of the state, social welfare changes are taking place at the level of health systems, in the sense of the state and society assuming responsibility for the health care of the population. There are a multitude of factors correlated with the size of funds that may be available for health: the tax base, the number of employees in the official sector, the number of poor households to be subsidized, the country's economy, etc. [2, p.124].

The financing mechanism of the national health system comprises 3 basic stages, reflected in figure 1. 
Figure 1. Stages of the national health system financing mechanism

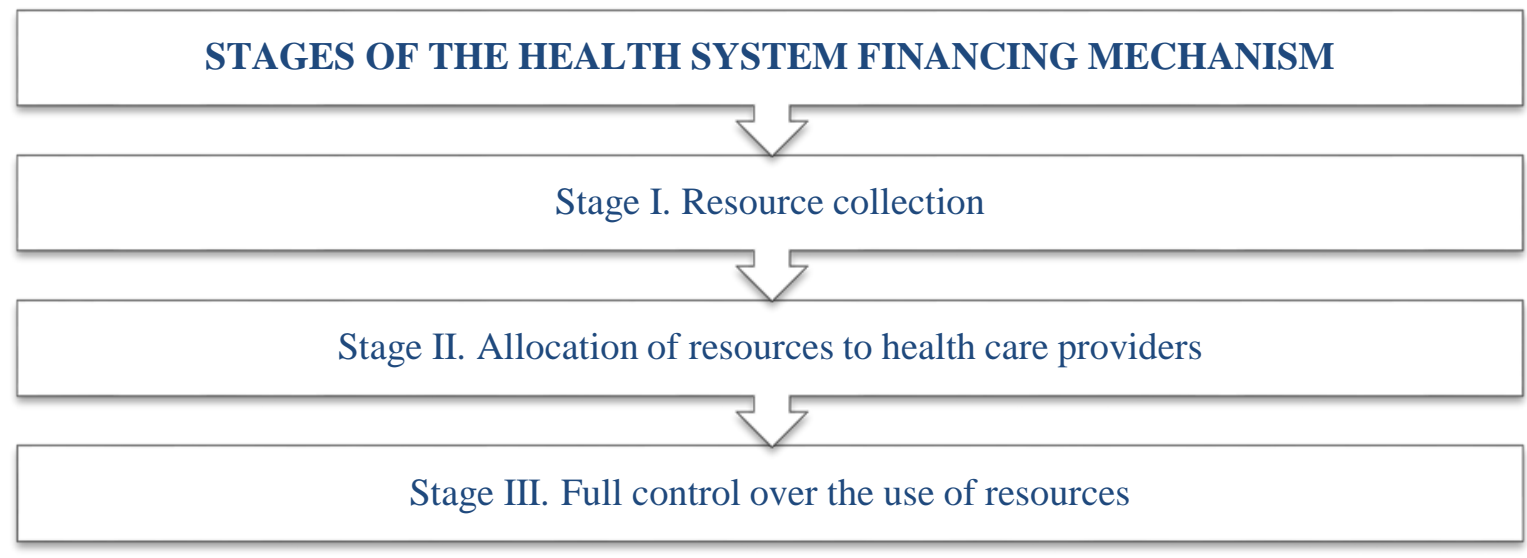

Source: compiled by the authors

In the first stage, the collection of the financing sources of the health system involves several sources, namely: compulsory medical contributions paid by the insured and the insurer, direct and indirect taxes, private health insurance premiums and direct payment of medical services by consumers. From the first stage derives the second one that of the resources' allocation, according to which the resources collected, through one of the mechanisms mentioned above, are allocated to the health care sectors (the primary, secondary and tertiary level) and medical service providers (hospitals, dispensaries, polyclinics, private offices). We consider the third stage as a tool for regulating and correlating the first stage and the second one, because by performing a rigorous and comprehensive control of the use of financial resources we will achieve performance in financing the financing system, as well as omitting the situations of the financial resources' inefficient use.

According to the authors, it is necessary to reconfigure the financing mechanisms of the health system, in order to streamline both the financial flows and their management mechanisms. In this context, we propose the observance of the following stages of the financing mechanism of the national health system:

Figure 2. Reconfigured national health system financing mechanism

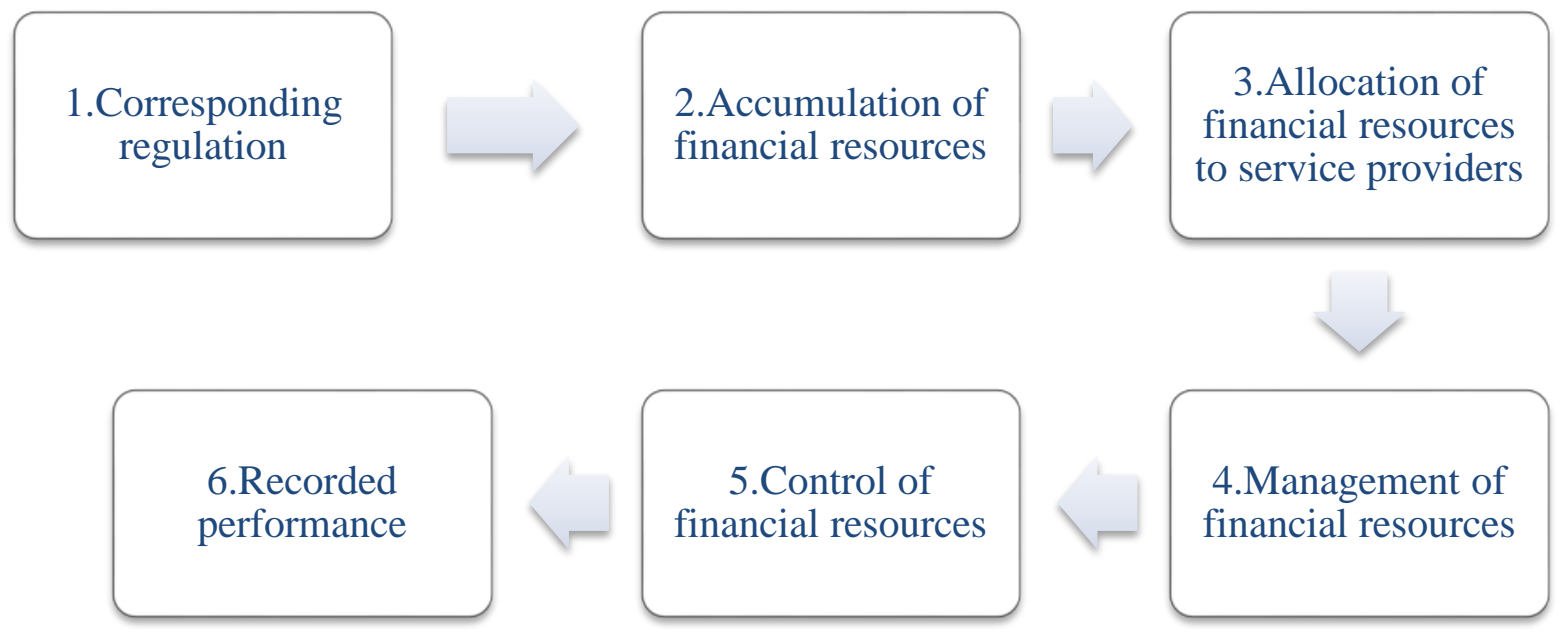


Source: compiled by the authors

Based on the fact that the funding mechanisms are affected by a number of endogenous and exogenous factors, we believe that the conjuncture proposed by the authors will allow the health system efficiency and modelling according to shocks and uncertainties that may arise along the way.

In this context, it is important to address the sources of financial resources for the health system, among which we can highlight: public sources, the accumulation of financial resources takes place on the FAOAM account (general taxes, medical contributions applied to employees and employers, external grants) and private sources, the accumulation of resources takes place through the economic circuit and represents the private income of the population, the rest being channelled to private health insurance, as shown in Figure 3 [1]. The distribution stage takes place through the participation of the intermediary of the National Medical Insurance Company (CNAM) in the case of public resources and directly by the beneficiaries or insurance companies in the case of private resources. Finally, the financial resources are used by the providers of medical services, represented by the public and private medical institutions, based on the contracts concluded with the CNAM, those with the insurance companies or the direct beneficiary-provider relations. Thus, the national health care system is the one based on the compulsory Bismark health insurance and is based on the insured's (CNAM) ability to pay, beyond the given limit being directly involved the beneficiary through private payments [1].

Figure 3. Sources of financing the health system in the Republic of Moldova

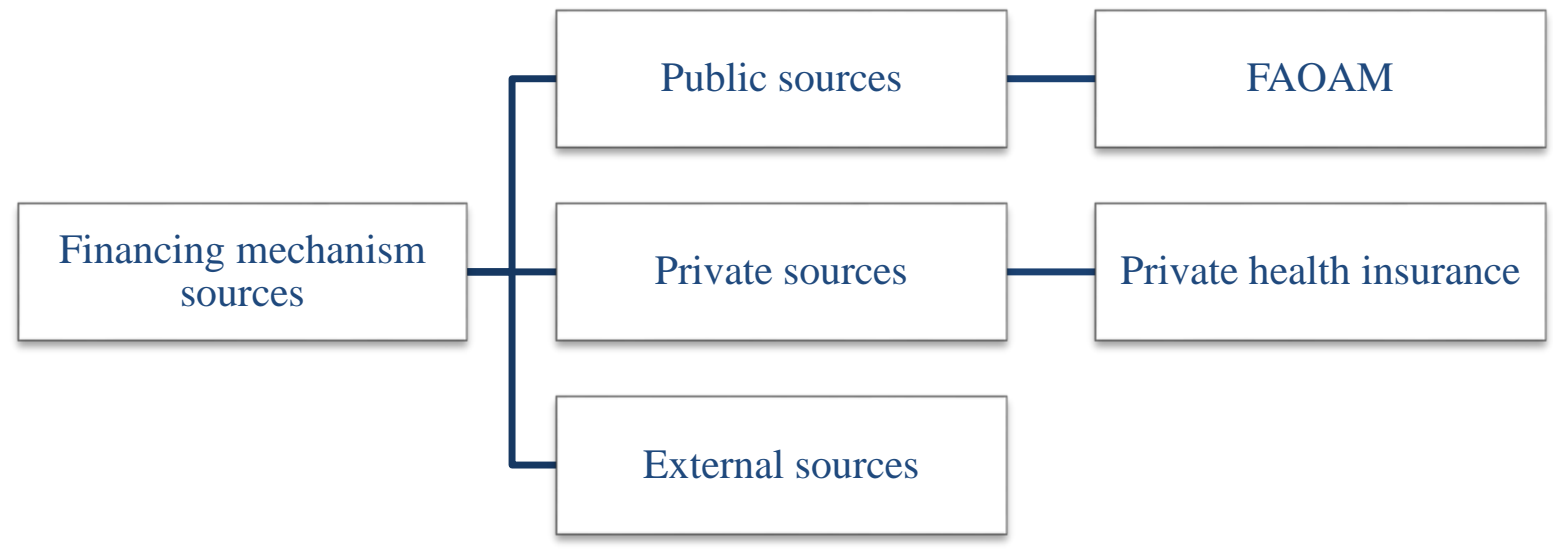

Source: compiled by the authors

According to the study conducted by the Independent Analytical Center "ExpertGrup", both public and private financial resources are involved in the national health system, including the external financial assistance [1]. Given that a large part of the expenditure of public medical institutions remains to be financed also from the medical services provided against payment to patients (private expenditure), the term "health expenditure" refers to all funds used by providers of health goods and services and include public funds, as well as private funds (personal expenses) incurred by the population when purchasing health goods and services, which are characterized by official and informal payments [1]. The official ones appear in the form of fees charged by private and public 
medical institutions, as well as the payments made for the purchase of medicines, and the unofficial ones represent the amounts in kind or cash granted voluntarily by patients to express their gratitude. At the same time, public spending on health care is reflected in the budget and transposes state policy in this area, while private spending on health is rather the need and opportunity for citizens to complete the public supply of health services [1]. In order to identify the opportunities for reconfiguring the financing mechanisms of the health system, it is necessary to study the financing systems in the European Union. Therefore, the European public health systems are structured on the basis of three funding models, as shown in figure 4.

The Beveridge model, developed and proposed by the British, is used in England, Norway, Denmark, Sweden, Finland, Ireland, Italy, Spain, Portugal and Greece. The main source of funding for this model is general taxes. The Bismarck model is used in the Netherlands, Belgium, Luxembourg, Switzerland, France, Germany and Austria. The model combines elements of social insurance (old-age pensions, compensation for temporary loss of work capacity) and medical (sickness insurance). It is currently the most widespread model in Europe. The Semashko model as a legacy of socialist governance, was specific to the countries of Central and Eastern Europe, which are in the transition process from a centralized to a market-based planning system. The financing of the health systems was made from the state budget. Most healthcare systems in Europe use a revenue mix to sustainably fund services. The system of compulsory health care insurance in the Republic of Moldova was designed and operates based on the principle of operation of the Bismarck model.

Figure 4. Classification of health systems according to the financing model

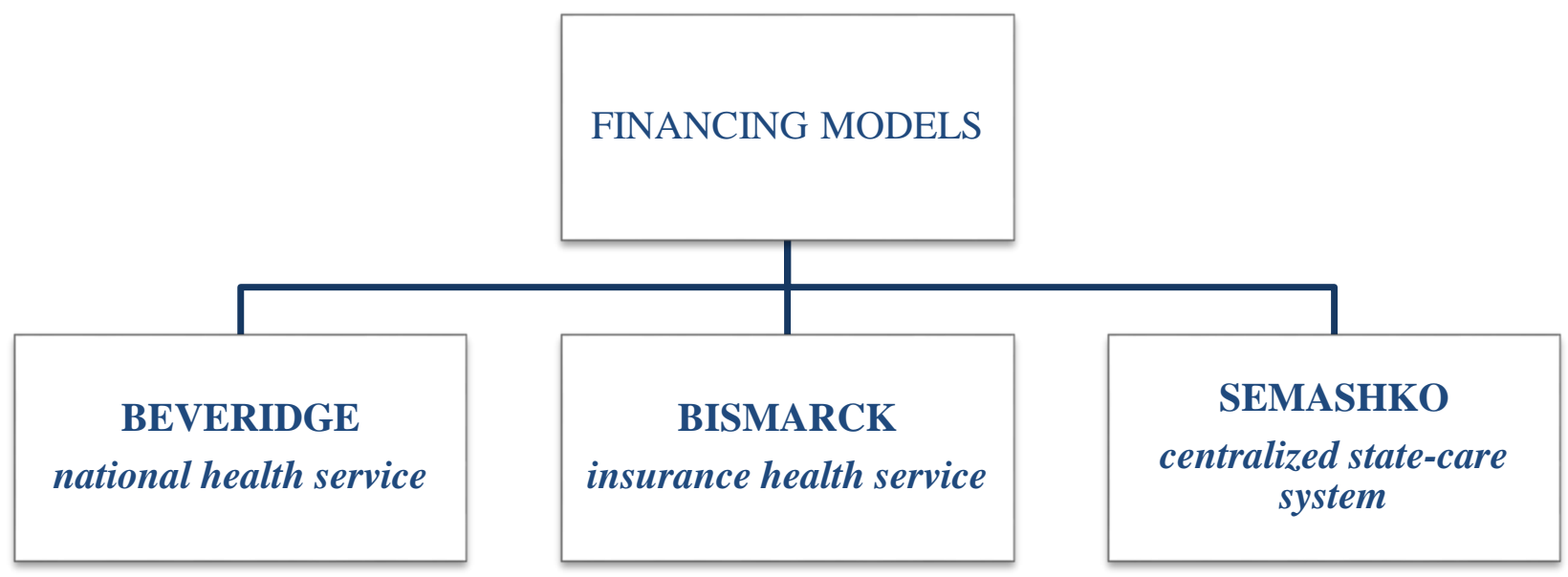

Source: compiled by the authors in base of [3]

We mention that in all the countries of the European Union, the governments are involved in the financing of the medical systems. Most Member States use a combined system between social security contributions and direct government funding for health. Each country has developed its own health system based on the political, social, cultural and economic context, but is specifically influenced by the experience of developed countries in the field. Each national health system seeks to respond to new challenges according to its own characteristics, which require ongoing assessments and adjustments. 
Thus, we cannot report on an ideal model that would serve as a standard for other systems [4]. The payment mechanisms used in the process of allocating financial resources to medical service providers are:

a) advance payment according to the advance case (a payment is granted for each case treated, depending on a predetermined cost);

b) budget broken down by categories of expenditures (the volume of the main elements of expenditures is established: personnel, medicines, food, materials, directing services, etc.); c) global budget (it is a payment mechanism through which a global amount is allocated for the achievement of a predetermined volume of activities, in a determined period of time);

d) practice budget (a group of general practitioners can obtain a budget for providing medical care for a certain number of patients);

e) payment based on diagnosis (it is a mechanism in which the provider receives a fixed payment, established in advance, each time he treats an individual with a certain specified diagnosis - DRGs).

The financing mechanisms of the national health system are based on financing from public funds, through contributions to compulsory health insurance. At present, the Republic of Moldova needs to reform this funding mechanism in order to provide better access to a range of necessary services and to improve health outcomes. From a financial point of view, the main challenges are finding additional financial resources needed for the system and making optimal use of them. Underfunding of the health system is often cited as one of the main problems in the country [3]. The sustainability of the national health system is imposed by the possibility of collecting the necessary revenues to cover current and future expenses. Therefore, the authors consider it imperative to adopt good practices and to follow the model of the EU Member States, including Romania, to supplement the source of revenue to the FAOAM budget, with the claw-back tax identified as a new source to be constituted as own income of the Ministry of Health and subsequently to be allocated by transfer to the FAOAM budget or directly revenues to the FAOAM budget, for medicines that benefit the insured in outpatient treatment, with or without personal contribution, on the basis of medical prescription, in the health insurance system [5].

The claw-back fee, being assimilated to a tax obligation for all drug manufacturers present on the market through the holders of marketing authorizations of drugs, in order to finance the necessary health services for the whole community. Through this system, manufacturers of medicines that make products contribute to the financing of the public health system with amounts set according to the volume of revenues obtained. This mechanism, which involves the return of an amount to the financier for the same destination is used by states such as the Netherlands, Hungary, Poland, Belgium, the United Kingdom, Portugal, Ireland and France [5].

The pandemic shocks that have affected the whole world force us to reconfigure the financing mechanisms of the national health system. That is why, in our opinion, in order to combat pandemic shocks, as well as crises in the health system, it is extremely important to take into account the good practices of different countries that have gone through these conditions. Even if there is no universal recipe developed to deal with the crisis in this area, each country still acts independently, taking into account the level of development and resources available. It is obvious, however, that so far there are no quick solutions to the shock and crisis. 
The possible solutions also differ according to the manifestations. The shocks that affected the global economy in the period before the official recognition of the crisis can be characterized as follows [6, p.31]:

- the general state of business in the global economy reflected the conjunction of three major shocks: rising prices; reducing the housing market in the US and some advanced countries; as well as the financial crisis. The interaction of these shocks has made it much more difficult to make economic and monetary policy decisions;

- commodity prices, even in the context of short-term reductions, are expected to remain high and volatile; however, if the commodity price trend is sustained, a new field for monetary, and in this case budgetary, counter-cyclical policies could be created;

- $\quad$ oil prices have moderated their growth, but uncertainty remains high, with signs of weak global growth indicating some demand response to high oil prices and improvements in supply conditions, which could lead to declining prices;

- however, the balance of supply and demand in the market remains tense, strong growth in demand, stimulated by accelerating resource activity and slow supply reactions in intensive emerging economies, leading to declining stocks and available capacity, which could high and volatile prices.

Originally generated, as mentioned before, by food and energy price shocks, the global financial crisis could significantly halt the fight against poverty. In a globalized world, where seemingly separate shocks and crises can quickly spread globally, the response must be global, coordinated, flexible and fast. The lessons of previous shocks and crises emphasize the importance of protective investments in long-term development, investments in infrastructure, in social development, in the quality of economic growth, etc. International financial institutions must help build bridges of multi-faceted policy responses to protect the poorest and most vulnerable economies from the immediate and long-term impact of the crisis, through actions aimed at supporting the financial and private sectors, assisting the developing countries within the process of managing the fiscal challenges to avoid long-term investment delays on which the relaunch and development depend [6, p.37].

In this context, we consider it relevant to attribute a new concept to the health system, namely the financial shock of the health care system, which in our opinion is welcome given that a number of problems persist in various areas that directly affect the revenues and expenditures of the health care system, in our case of the health system.

According to researchers Mladovsky P. and others, the global financial crisis that began in 2007 can be classified as a shock of the health system - that is, an unexpected event caused outside the health system, which has a negative effect on the availability of system resources, or a positive effect on the demand for medical services [8].

We draw attention to the fact that the shock can be a medical one not only the financial one, for example the COVID-19 pandemic, which caused both an economic and a medical (pandemic) shock. Why medical? Because all countries in the world have been affected by the pandemic, and health systems have largely gone through a medical shock that has led the systems into a deep coma. If we make a remark, the medical systems, especially the medical staff, were the most exposed to the medical shock, which caused the medical crisis, lack of doctors, nurses, attendants, inability to space, beds to hospitalize all patients. 
Currently, pandemic and economic shocks affect health decision-makers in three basic ways [8]:

$\rightarrow$ Health systems require the estimation of revenues depending on the investment plan, determine budgets and the purchase of goods and services. Sudden cessation of budget allocations can cause major difficulties in providing healthcare.

$\rightarrow$ The decline in public spending on the health system as a result of the economic shock occurs when the health system requires more resources, such as addressing the effects of unemployment on health.

$\rightarrow$ Abusive reductions in basic health services can further destabilize the health system, if financial stability, equitable access to health services, and the quality of services provided, the increase in health and other long-term costs are affected.

Thus, the financial shock of the health care system - is a risk (a condition) that can generate problematic situations in many areas, which have a direct impact on health system revenues and expenditures, these problems, compiled can have serious consequences on both the system and of its performance. It is important to note that, in order to ensure the financial sustainability in the face of the financial crisis, as well as to improve fiscal preparedness in the health sector for financial crises, policies should be in line with the fundamental objectives of the health system.

If the health system is facing an economic shock, or financial crisis, decisionmakers must provide in national health policy the possibility of maintaining, reducing or increasing the level of health spending. It becomes imperative to reallocate funds within the health system to increase its efficiency. For this purpose, a number of tools can be used to change the level of expenditure, in order to maintain the system as well as the application of an anti-shock therapy. In pandemic shocks, achieving the goals of the health system can be achieved through a series of actions, such as [8]:

- health status: improvement of medical results and services provided;

- financial security: accessibility of the population to the requested medical assistance;

- efficiency: maximizing the health benefit in relation to the allocated resources and not admitting waste;

- equity: the provision of distributed health services in relation to the requirements of the population, and the contributions are established according to the ability to pay for the service;

- quality: represents the effectiveness of the clinical work expressed on the patient, which ensures safety, efficiency, accessibility, acceptability;

- reaction capacity: patients' expectations regarding non-medical actions, the way they are approached;

- transparency: providing reliable information on the characteristics of the health system, such as benefits, costs and quality;

- responsibility: monitoring and evaluation of performance, which is associated with tangible consequences (penalties).

We reiterate that worldwide health systems face budgetary problems when the level of public spending on health per capita does not correspond to the increase in demand for health services, they have fallen sharply despite the fact that demand is stable or growing. In the event of a pandemic, the economic problems of the public sector can be caused by several factors, such as: the financing policy of the health sector, the diminishing role of the public health strategy and social adaptation, used in financially vulnerable families 
[10]. Any shock, be it pandemic or economic, presents a risk that can generate multiple health problems, affecting both government and household incomes and expenditures. These challenges can have serious consequences for the health of the population, as well as for the efficiency of the functioning of the national health system. Shocks, in general, have a direct impact on the health of the population, as the needs for medical services increase.

From the model presented, we conclude that the health system faces financial problems if government spending on per capita health does not match the rising or falling demand. The model presented demonstrates how important are the financing mechanisms of the health system, because the health status of the population depends on them, first of all. In shocking conditions, health system funding mechanisms need more attention to meet new challenges, so this must be a key concern for the administrative management responsible for the effective functioning of the national health system.

Figure 5. Model for reducing indicators on the health status of the population in conditions of pandemic or economic shocks

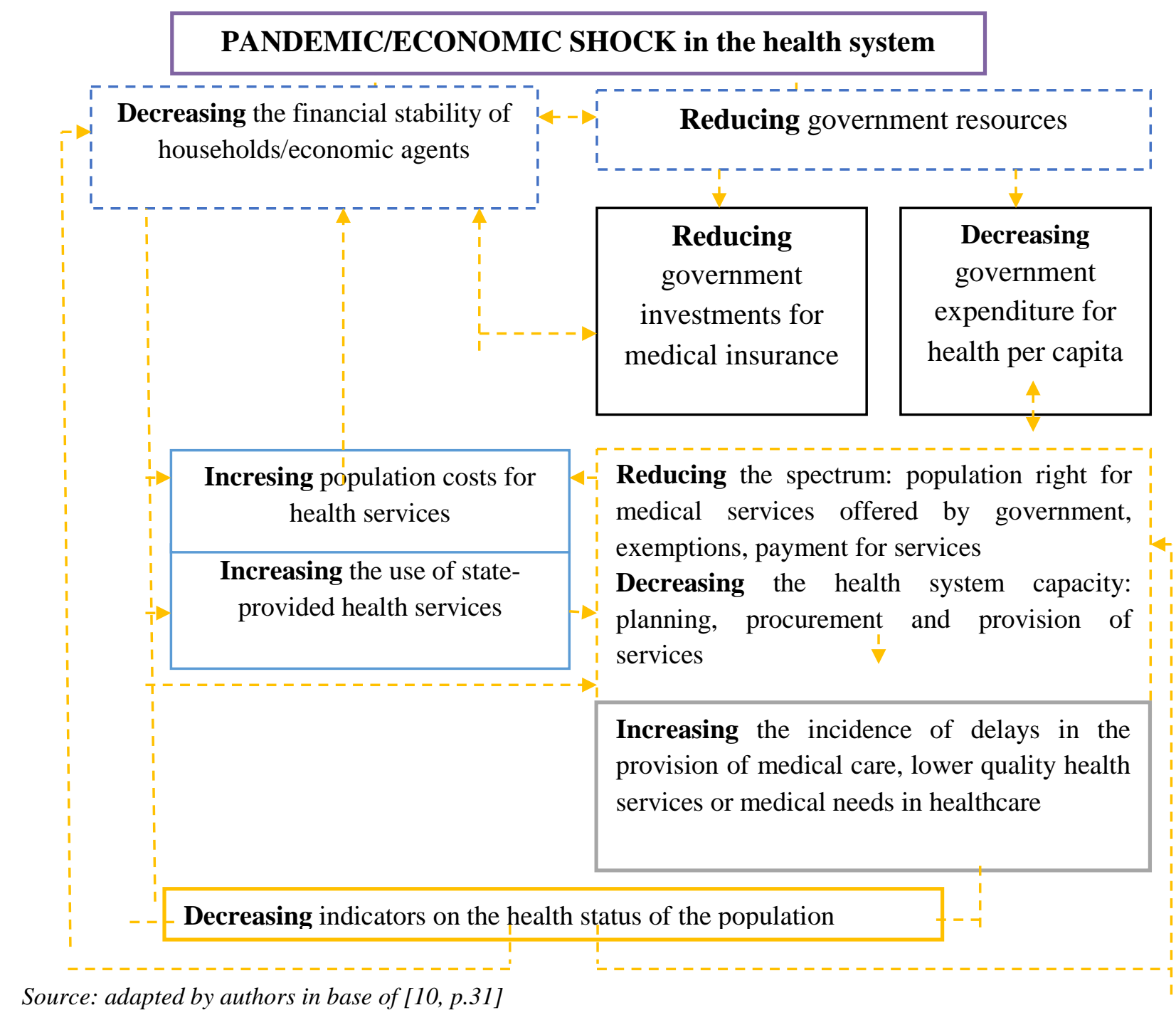


In conclusion, we specify that shocks and pandemic crises have destructive effects for countries with a poorly developed level, including the Republic of Moldova, which do not have sufficient financial support. Thus, being unable to obtain financial income to cover the necessary public expenditures or the impossibility to generate additional revenues, it led to the maximum reduction of public expenditures for the health field. In this context, being under the pressure of reducing public spending, the national health system was also affected. Research suggests that public spending on health in Europe has tended to decline after previous shocks and crises, often at a faster pace than other types of government spending. Therefore, the health system is vulnerable to depletion of financial resources from the national public budget, so it is necessary to identify new additional sources of collection of financial resources.

\section{Conclusions and suggestions}

The current structure of the financing mechanism of the national health system needs improvements, so as a prerequisite for the reform we propose to intensify internal control at each stage of the mechanism: collection, regulation, allocation, management, control of use of financial flows and financial performance. In general, this approach involves the funding mechanisms' reconfiguring, which will ensure the financial sustainability of the national health system. There is also a need to strengthen the capacity for efficient and modern governance of funding mechanisms in order to improve the health system, the health of the population, including the financial security, equity in the allocation of financial resources to health care providers, equitable access to health care, the quality and safety of the medical services provided, patient satisfaction, transparent and efficient management of financial flows for the health system.

In order to reconfigure the financing mechanisms of the national health system, we consider that the Republic of Moldova needs smart investments in the field of health. Therefore, for the proper functioning of the national health system we propose:

- the development of the national economy and the increase of the allocations for the health system;

- reconfiguration of the current financing mechanisms, through regulation, accumulation, allocation, management but also rigorous control of financial flows within the FAOAM;

- implementation of the mechanism for collecting financial resources through the claw-back tax, based on good practices, so that it is a new source of income for the national health system;

- consolidating the number of people who contribute to the system of compulsory health insurance;

- $\quad$ the budgets of the health system do not necessarily have to be bigger, but to be spent more intelligently (streamlining the use of available financial resources);

- strengthening investments in health, especially health promotion programs;

- increasing investments in health insurance, in order to reduce inequalities and social exclusion;

- prioritization of the health system by government institutions, in the process of distributing financial resources; 
- harmonization of the financing mechanisms of the health system through the financing oriented on legislative criteria and SMART objectives, performance indicators, by harmonizing the legislative framework, which will ensure the sustainability and functionality of the health system in conditions of shocks or pandemic crises.

Finally, we conclude that the shock and crisis situations have highlighted the shortcomings of the mechanisms for financing the national health system, and to overcome the major challenges we need concrete objectives and appropriate tools to reset and modernize both the mechanisms and the health system.

Acknowledgments. This paper is developed within the project "Human Rights in the Republic of Moldova: financial dimension and consolidation through the sufficient public experiences management" (code 20.80009.0807.35), funded through the National Agency for Research and Development of the Republic of Moldova under the State Program 2020-2023.

\section{References}

1. Centrul Analitic Independent "Expert-Grup”. Eficiența și transparența sistemului de sănătate din Republica Moldova, $2018 . \quad$ Ianuarie Disponibil: https://expertgrup.org/media/k2/attachments/Eficienya_ui_transparenya_sistemului_de_sInItate_din_Republica_Moldov a.pdf.

2. Copăceanu C. Finanţarea sistemului de sănătate: experienţe şi oportunităţi. În: Economie şi sociologie, 2011, nr 3, p.124-129.

3. $\quad$ Copăceanu C., Asigurarea eficienței mecanismului de finanţare a sistemului ocrotirii sănătății în Republica Moldova. Monografie. Iași: Vasiliana 98, 2015. ISBN: 978-973-116-416-8

4. $\quad$ Ganea V., Copăceanu C. The forms of organization and financing of the health system: experiences and opportunities. În Revista "Meridian Ingineresc", Chişinău, 2012, nr.2, p.77-79

5. Iliescu A. Finanțarea sistemului de sănătate în România prin venituri publice. Management $\hat{\imath}$ sănătate, $\quad \mathrm{XVI} / 4 / 2012, \quad$ p. $3-5 . \quad$ Disponibil: http://journal.managementinhealth.com/index.php/rms/article/viewFile/245/768/

6. Manolescu Gh.. Politica monetară în condiţile crizei financiare globale. Disponibil online: ftp://www.ipe.ro/RePEc/vls/vls_pdf/vol13i1p28-39.pdf.

7. Maxim I. Perfecţionarea mecanismului de finanţare a întreprinderii în perioada instabilităţii economice. Chişinău, ASEM, 2003, p.8.

8. Mladovsky, P., Srivastava, D., Cylus, J. et al. (2012) Health Policy Responses to the Financial Crisis in Europe, Policy Summary 5. Copenhagen: WHO Regional Office for Europe on behalf of the European Observatory on Health Systems and Policies. http://www.euro.who.int/_data/assets/pdf_file/0009/170865/e96643.pdf

9. Russu Gh. Asigurarea medicală obligatorie în Moldova. Probleme-cheie referitoare la implementare. Manual: Aspecte economice şi financiare în reformarea sistemului de sănătate. Chişinău, 2002, p.27.

10. Thomson Sarah, Figueras Josep, и.д. Экономический кризис, системь здравоохранения и здоровье населения в в Eвропе. Disponibil: https://apps.who.int/iris/bitstream/handle/10665/332137/9789289050357-

rus.pdf?sequence $=1 \&$ is Allowed $=y$.

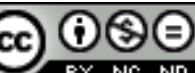

This article is an open access article distributed under the terms and conditions of the Creative Commons Attribution - Non Commercial - No Derivatives 4.0 International License. 